\title{
STUDIES ON FORMULATION AND EVALUATION OF ETHYL CELLULOSE BASED EXTENDED RELEASE METFORMIN HYDROCHLORIDE MATRIX TABLETS
}

\author{
SUNDARA MOORTHY K ${ }^{1,2 *}$, SAMPATH KUMAR KP ${ }^{3}$ \\ ${ }^{1}$ Department of Pharmaceutics, VELS University, Pallavaram, Chennai, Tamil Nadu, India. ${ }^{2}$ Department of Pharmaceutics, Adhiparasakthi \\ College of Pharmacy, Melamaruvathur, Tamil Nadu, India. ${ }^{3}$ Department of Pharmacy, Coimbatore Medical College, Coimbatore, Tamil Nadu, \\ India. Email: kaliyan123@rediffmail.com
}

Received: 03 August 2016, Revised and Accepted: 08 August 2016

\section{ABSTRACT}

Objective: Monolithic matrix tablets of metformin hydrochloride were formulated as extended-release tablets by employing ethyl cellulose (EC) polymer and the extended release characterization of the formulated tablets was investigated.

Methods: Extended release matrix tablets containing $500 \mathrm{mg}$ metformin hydrochloride were developed by changing concentration of drug: Polymer (EC) in the ratio of 5:1, 5:2, 5:3, and 5:4 by direct compression. Formulations were optimized based on the acceptable tablet properties in vitro and in vivo drug release.

Results: The resulting formulations produced robust tablets with optimum hardness, weight variation, drug content, and low friability. The result of in vitro and in vivo drug release studies indicated that formulation (drug:polymer=5:3) is the most successful of the study and exhibited constant and extended release of metformin hydrochloride release at the end of $10 \mathrm{hrs}$ compared with a reference standard. A decrease in release of the drug was observed on increasing polymer ratio at a certain level. Further, the formulation $\mathrm{F}_{3}$ was subjected to exposure at room and accelerated condition to stability studies. There is no difference between storage temperatures.

Conclusion: The formulation $\mathrm{F}_{3}$ was concluded that the similar in vitro and in vivo drug release pattern was observed when compared to marketed sustained release tablet $\left(\mathrm{F}_{5} \mathrm{M}\right)$.

Keywords: Metformin hydrochloride, Matrix tablets, Extended release and ethyl cellulose.

(C) 2016 The Authors. Published by Innovare Academic Sciences Pvt Ltd. This is an open access article under the CC BY license (http://creativecommons. org/licenses/by/4. 0/) DOI: http://dx.doi.org/10.22159/ajpcr.2016.v9i6.14478

\section{NTRODUCTION}

Metformin hydrochloride is an orally administered biquanide, which is widely used in the management of Type 2 diabetes, a common disease that combines defects of both insulin secretion and insulin action [1] It improves hepatic and peripheral tissue sensitivity to insulin without the problem of serious lactic acidosis commonly found with us analog, phenformin. It has 3 differentactions: (1) It shows the absorption at sugar in our small intestine, (2) it also stops our liver from converting stored sugar into blood sugar, and (3) it helps our body use our natural insulin more efficiently. It is hydrophilic drug and is slowly and incompletely absorbed from the gastrointestinal (GIT) tract and the absolute bioavailability of a single $500 \mathrm{mg}$ dose is reported to be $50-60 \%$ [2]. An obstacle to more successful use of metformin therapy is the high incidence of concomitant GIT symptoms such as abdominal discomfort, nausea, and diarrhea. Those especially occur during the initial weeks of treatment. The compound has also relatively short plasma elimination half-life of 1-4 hrs [3,4]. Side effect and the need for administration two or three times per day when larger doses are required can decrease patient compliance. Extended release formulation that would maintain plasma levels of drug for 8-12 hrs might be sufficient for once daily dosing for metformin. Extended-release (sustained release) products are needed for metformin to prolong us the duration of action and to improve patient compliance [2,5].

Several authors have reported the use of ethyl cellulose (EC) matrices to control the release of variety of drugs such as zidovudine, cimetidine, potassium chloride, isosorbide dinitrate, and theophylline, etc., for a variety of reasons. Therefore, in this study, the different concentrations of hydrophobic polymer (EC) have been used as matrix material to get the required release profile of metformin hydrochloride [6-10].

\section{MATERIALS AND METHODS}

\section{Materials}

Metformin hydrochloride - USP was gift sample from wockhardt pharmaceuticals (Mumbai, India), EC (18 cP) was procured from so fine Chemicals Ltd. (Mumbai, India). Micro crystalline cellulose powder I.P. was obtained from Sigha Enichlro Chemicals Pvt. Ltd., (India). Sodium Chloride injection IP. Mount Mettur Pharmaceutical Ltd., (Tamil Nadu, India). Alloxan, Loba Chemie (Bombay, India). All other chemicals and reagents used were of the high analytical grade. Double distilled water was used for evaluation studies.

\section{Machineries}

Machineries and equipment used were tablet compression machine, (Cadmach Machinery Co. Pvt. Ltd.). Ultraviolet (UV)-visible spectrophotometer, (Shimadzu 1700); six stage dissolution rate test apparatus IP/BP/USP, (tab machines). Friability test apparatus (Remi equipment Pvt. Ltd.). Monsanto hardness test apparatus, (Rollex Pvt. Ltd.) India, B. S. Sieves, (Jaynant scientific) and tray dryer (Mumbai engineering works). Differential scanning colorimeter (perkin elemer differential scanning calorimetry [DSC]-7 model) blood glucose monitoring system (smartcare TD-4227), saify traders (Indore, India). Stability chamber (environmental chamber). The Ileco, (Chennai, India).

\section{Animals}

Swistar albino rats (200-250 g) from Central Animal House, Adhiparasakthi College of Pharmacy, (Melmaruvathur, Tamil Nadu, India) were used in this study. The protocol for the animal experiment was approved by Institutional Animal Ethics Committee which follows the norms of CPCSEA (India). 


\section{Methods}

Preparation of metformin hydrochloride extended release matrix tablets

Different tablet reformulations $\mathrm{F}_{1}$ to $\mathrm{F}_{4}$ were prepared by direct compression technique [15]. Ingredients required for per tablet are given in Table 1 and tabulated as follows. The metformin hydrochloride, EC (18 cps) and microcrystalline cellulose (Avicel) powders were separately passed through mesh No: 44. Powders were uniformly blended in a double cone blender for 5 minutes. Then, the dried powders were lubricated with magnesium stearate and aerosil by mixing in a rapid mixer at slow speed for 5 minutes. Separately each formulation was compressed using 16/32 inch flat punches in Cadmach tablet compression machine to get tablets.

\section{Evaluation of powder blends}

The formulated powder blends were evaluated for compatibility, angle of repose, bulk density, true density, percentage compressibility index and total percentage porosity.

\section{Evaluation of tablets}

The compressed tablets formulations $\left(\mathrm{F}_{1}\right.$ to $\left.\mathrm{F}_{4}\right)$ and reference standard $\left(\mathrm{F}_{5} \mathrm{M}\right)$ (marketed sustained release tablet) were evaluated for hardness, percentage friability, percentage weight variations, and the percentage drug content.

\section{In vitro release studies}

The in vitro dissolution studies were carried out $[20,21]$ all formulated tablet $\left(\mathrm{F}_{1}\right.$ to $\left.\mathrm{F}_{4}\right)$ out using six stage dissolution test apparatus IP/BP/USP at $50 \mathrm{rpm}$. The dissolution medium consisted of simulated gastric fluid (pH 1.2-acid buffer) (for first $2 \mathrm{hrs)} \mathrm{and} \mathrm{followed} \mathrm{in} \mathrm{simulated} \mathrm{intestinal}$ fluid ( $\mathrm{pH} 7.2$-phosphate buffer) from 2 to $10 \mathrm{hrs}(900 \mathrm{ml})$, maintained at $37^{\circ} \mathrm{C} \pm \pm 0.5^{\circ} \mathrm{C}$. Samples were taken at predetermined time intervals and analyzed for metformin hydrochloride content at $227.5 \mathrm{~nm}$ and $230 \mathrm{~nm}$ in UV-visible spectrometer, respectively, and compared with the blank. The same procedure was followed reference standard $\left(\mathrm{F}_{5} \mathrm{M}\right)$.

\section{In vivo release studies}

Diabetes was induced in healthy Wistar albino rats of either sex weighing (200-250 g) by injecting a single intraperitoneal injection of $150 \mathrm{mg} / \mathrm{kg}$ body weight of alloxan monohydrate. Blood glucose level was checked after $48 \mathrm{hrs}$. Animal with blood glucose level $>250 \mathrm{mg} / \mathrm{dl}$ were considered diabetic and were selected for our further study [25-27].

The rats were divided into 4 groups of rats each group having 6 rats and Group I animal served as normal control, they were not given any drug. The Groups II, III, and IV were diabetic rats. From the Groups (II-IV), Group II animal are diabetic control rats. The Groups III and IV were given formulated metformin hydrochloride matrix tablet formulation $\mathrm{F}_{3}$ and reference standard $\left(\mathrm{F}_{5} \mathrm{M}\right)$, respectively, in the form of suspension orally at a dose level of $450 \mathrm{mg} / \mathrm{kg}$ body weight. On fasting, blood samples were collected from the tail vein on the $3^{\text {rd }}$ day of each Groups (I-IV) at 0, 1, 2, 4, 6, 8, $10 \mathrm{hrs,} \mathrm{intervals.} \mathrm{Glucose} \mathrm{levels} \mathrm{were} \mathrm{estimated}$ using glucosemeter. Statistical comparisons with animal of non-treated groups of control I and II with drug-treated groups were performed with Student's $t$-test. Data were expressed as mean \pm standard error mean.

\section{RESULTS AND DISCUSSION}

Metformin hydrochloride is a highly water-soluble drug. Its poor inherent compressibility coupled with high dose (500 mg) a significant challenge for developing an extended release dosage form. For developing extended release matrix tablet with desirable drug release profile, cost effectiveness and broader regulatory acceptance, different concentration EC (18 cP) was chosen as a release controlling polymer.

Compatibility study of metformin hydrochloride by DSC

DSC thermogram of pure metformin hydrochloride and blend of polymer mixture with drug were determined (Fig. 1) [11-13]
Different in the peak area in the thermograms of blend of drug in the polymer from that of pure drug is due to less quantum of drug in the blend. Absence of any new endothermic peak is disappearance of no shift of endothermic peak confirm that peak in thermogram of pure drug and the blend of drug in the polymer confirms that there is no any interaction, and hence the polymer are compatable with the drug.

\section{Evaluation of physico-chemical parameters of formulated powder} blends

Formulation of proper powder blend is the key factor in the production of tablet dosage form involving extended release of a drug from matrix type particle. Physical parameters such as specific surface area, shape, hardness, surface characteristics and size can significantly affect the rate of dissolution of drugs contained in a complex system. The formulated powder blends of different formulations $\left(F_{1}\right.$ to $\left.F_{4}\right)$ were evaluated for angle of repose, true density, bulk density, compressibility index, and total percentage porosity [14-17] (Table 2). The results of angle of repose $(<30)$ indicated good flow properties of all the formulated powder blends except one $\left(\mathrm{F}_{4}\right)$. The compressibility index value recorded $<15 \%$, results in good to excellent flow properties in two formulations $\left(\mathrm{F}_{2}\right.$ and $\mathrm{F}_{3}$ ) supporting the angle of repose indicating good flow, which in rest of the formulation it can $>15 \%$.

The formulated powder blend density, porosity and hardness are often interrelated properties and are likely to influence compressibility, porosity, dissolution profile and other properties of tablets made from it, the percentage porosity value ranged from $8.89 \%$ to $29.13 \%$ indicating that the packing of the powder blend may range from close to loose packing and also confirm that the particle is not of greatly different sizes. In general, a percentage porosity value below $26 \%$ shows that the particle in the powders are of greatly different sizes, and a values $>4.8 \%$ percentage shows that particle in the powder are in the form aggregates or flocculates. All these results indicate that the formulated powder blends processed satisfactory flow properties and compressibility.

\section{Evaluation of formulated tablets}

The tablet of different formulations $\left(\mathrm{F}_{1}\right.$ to $\left.\mathrm{F}_{4}\right)$ and reference standard $\left(\mathrm{F}_{5} \mathrm{M}\right)$ was evaluated for various parameters, viz., hardness, friability, \% weight variation, and $\%$ drug content. The results of these parameters are given in Table 3. The results are compared with the reference standard $\left(\mathrm{F}_{5} \mathrm{M}\right)$ and also confirm with the official and OPPI standards for tablets [18-21]

Table 1: Composition of tablet formulations $F_{1}$ to $F_{4}$

\begin{tabular}{lllll}
\hline Ingredients (per tablet) (mg) & \multicolumn{3}{l}{ Formulations } \\
\cline { 2 - 5 } & $\mathbf{F}_{\mathbf{1}}$ & $\mathbf{F}_{\mathbf{2}}$ & $\mathbf{F}_{\mathbf{3}}$ & $\mathbf{F}_{\mathbf{4}}$ \\
\hline Metformin hydrochloride & 500 & 500 & 500 & 500 \\
Ethyl cellulose (18 centipoise) & 100 & 200 & 300 & 400 \\
Microcrystalline cellulose & 75 & 75 & 75 & 75 \\
Colloidal silicone dioxide (aerosil) & 0.006 & 0.006 & 0.006 & 0.006 \\
Magnesium stearate & 0.012 & 0.012 & 0.012 & 0.012 \\
\hline
\end{tabular}

Table 2: Physical and chemical parameters of formulated metformin hydrochloride powder blends with polymers $\left(\mathrm{F}_{1}\right.$ to $\left.\mathrm{F}_{4}\right)$

\begin{tabular}{lllll}
\hline \multirow{2}{*}{ Evaluation parameters } & \multicolumn{3}{l}{ Formulations } \\
\cline { 2 - 5 } & $\mathbf{F}_{\mathbf{1}}$ & $\mathbf{F}_{\mathbf{2}}$ & $\mathbf{F}_{\mathbf{3}}$ & $\mathbf{F}_{\mathbf{4}}$ \\
\hline Angle of repose (degree) & 23.35 & 23.19 & 23.75 & 30.02 \\
Bulk density (g/ml) & 0.69 & 0.58 & 0.56 & 0.65 \\
Compressibility index (\%) & 16.05 & 12.72 & 12.72 & 16.67 \\
Porosity (\%) & 29.13 & 11.40 & 11.40 & 18.89
\end{tabular}


In vitro release studies

Results of the in vitro release studies and manufactured along with reference standard formulation (a marketed sustained release product) are presented in Tables 4-6 are shown in Fig. 2.

The plot of cumulative percentage in vitro drug release profile of metformin hydrochloride from four formulations $\mathrm{F}_{1}, \mathrm{~F}_{2}, \mathrm{~F}_{3}$, and $\mathrm{F}_{4}$ made with different concentration of EC $(18 \mathrm{cP})$ in simulated gastric fluid (pH 1.2-acid buffer) (for first 2 hrs) followed by simulated intestinal fluid (pH 7.2-phosphate buffer) [20,21] for $10 \mathrm{~h}$ is shown in Fig. 3. It is found that the cumulative percentage drug release of the formulation $\mathrm{F}_{1}$ is faster than formulations $\mathrm{F}_{2}, \mathrm{~F}_{3}$, and $\mathrm{F}_{4}$, with formulation $\mathrm{F}_{4}$ showing the

Table 3: Physical and chemical parameters of formulated metformin hydrochloride compressed tablet formulations $\left(F_{1}\right.$ to $\left.F_{4}\right)$ and marketed formulation (FM)*

\begin{tabular}{llllll}
\hline Evaluation parameters & \multicolumn{7}{l}{ Formulations } \\
\cline { 2 - 6 } & $\mathbf{F}_{\mathbf{1}}$ & $\mathbf{F}_{\mathbf{2}}$ & $\mathbf{F}_{\mathbf{3}}$ & $\mathbf{F}_{\mathbf{4}}$ & $\mathbf{F M}$ \\
\hline Hardness (kg/cm $\left.{ }^{2}\right)$ & 8.00 & 8.33 & 8.67 & 8.00 & 8.00 \\
Friability (\%) & 0.78 & 0.59 & 0.55 & 0.33 & 0.39 \\
Weight variation (\%) & 0.63 & 0.86 & 0.56 & 1.10 & 0.51 \\
Drug content (\%) & 99.40 & 99.20 & 100.20 & 99.20 & 100.4 \\
\hline
\end{tabular}

slowest release and unsatisfactory. Release profile of $\mathrm{F}_{3}$ is comparable to reference standard $\left(\mathrm{F}_{5} \mathrm{M}\right)$. Hence, it can be inferred that a proportion of EC (18 centipoise) is increased to release is retarded and drug: EC ratio of $5: 3$ is found to be optimum for comparable release profile of reference standard $\left(\mathrm{F}_{5} \mathrm{M}\right)$.

\section{Stability studies on in vitro release}

The selected formulation $\mathrm{F}_{3}$ was subjected up to 6 months stability study as per International Congress on Harmonization (ICH) guidelines at room temperature $\left(25^{\circ} \mathrm{C} \pm 2^{\circ} \mathrm{C}\right.$ and $60 \% \pm 5 \%$ relative humidity [RH]) and accelerated condition $\left(40^{\circ} \mathrm{C} \pm 2{ }^{\circ} \mathrm{C}\right.$ and $\left.75 \% \pm 5 \% \mathrm{RH}\right)$ to find out the effect of aging on release pattern [24]. The results of the stability study do not indicate any significant alteration in the in vitro release pattern of the drug from the tablet. The results are furnished Tables 7-10 and presented graphically in Fig. 4.

Cumulative percentage release versus time plot drug release data from selected formulation $\mathrm{F}_{3}$, after 6 months of exposure to stability testing condition at room temperature and accelerated condition as per ICH guidelines in simulated gastric fluid (pH1.2-acid buffer) (for first $2 \mathrm{hrs}$ ) followed by stimulated intestinal fluid ( $\mathrm{pH}$ 7.2-phosphate buffer). The data are shown in Tables 5 and 6 depicted in Fig. 4. There is no significant difference in the in vitro release formulation $\mathrm{F}_{3}$ and compared with a reference standard $\left(\mathrm{F}_{5} \mathrm{M}\right)$ before and after stability studies.

Table 4: Comparative in vitro release profiles on metformin hydrochloride matrix tablet formulations $\left(F_{1}\right.$ to $\left.F_{4}\right)$ and reference standard $\left(\mathbf{F}_{5} \mathbf{M}\right)^{*}$

\begin{tabular}{|c|c|c|c|c|c|c|}
\hline Time (minutes) & pH & $F_{1}$ & $\mathbf{F}_{2}$ & $\mathbf{F}_{3}$ & $\mathbf{F}_{4}$ & $\mathbf{F}_{5} \mathbf{M}$ \\
\hline \multirow[t]{2}{*}{30} & pH 1.2 (Simulated gastric fluid) & $21.10 \pm 1.17$ & $18.35 \pm 1.11$ & $16.24 \pm 2.08$ & $10.86 \pm 1.78$ & $19.98 \pm 0.03$ \\
\hline & & 5.56 & 6.03 & 12.78 & 16.38 & 0.13 \\
\hline \multirow[t]{2}{*}{60} & & $28.7 \pm 1.69$ & $25.78 \pm 1.54$ & $22.80 \pm 3.51$ & $14.86 \pm 2.45$ & $28.86 \pm 1.40$ \\
\hline & & 5.88 & 5.98 & 8.53 & 16.50 & 4.86 \\
\hline \multirow[t]{2}{*}{90} & & $37.73 \pm 2.60$ & $31.17 \pm 1.46$ & $28.84 \pm 1.17$ & $16.09 \pm 2.83$ & $38.36 \pm 1.75$ \\
\hline & & 6.90 & 4.68 & 4.04 & 13.59 & 4.57 \\
\hline 120 & & $50.2 \pm 1.24$ & $48.14 \pm 2.00$ & $42.29 \pm 2.54$ & $21.27 \pm 2.82$ & $43.90 \pm 2.69$ \\
\hline \multirow[t]{2}{*}{150} & pH 7.2 (Simulated intestinal fluid) & $71.63 \pm 2.56$ & $61.66 \pm 2.68$ & $50.56 \pm 1.38$ & $25.86 \pm 1.08$ & $52.57 \pm 1.32$ \\
\hline & & 3.57 & 4.35 & 2.73 & 4.17 & 2.52 \\
\hline \multirow[t]{2}{*}{180} & & $81.42 \pm 2.34$ & $68.96 \pm 1.37$ & $59.38 \pm 1.18$ & $28.26 \pm 1.35$ & $58.27 \pm 2.12$ \\
\hline & & 2.88 & 1.99 & 1.99 & 4.78 & 3.63 \\
\hline \multirow[t]{2}{*}{240} & & $99.84 \pm 0.23$ & $80.96 \pm 2.10$ & $68.93 \pm 1.87$ & $30.55 \pm 2.08$ & $67.72 \pm 2.70$ \\
\hline & & 0.23 & 2.59 & 2.71 & 6.80 & 3.98 \\
\hline \multirow[t]{2}{*}{360} & & - & $99.28 \pm 0.43$ & $76.62 \pm 1.35$ & $33.23 \pm 2.64$ & $79.90 \pm 0.79$ \\
\hline & & & 0.44 & 1.70 & 7.93 & 0.99 \\
\hline 420 & & & & 2.99 & 8.55 & 2.38 \\
\hline \multirow[t]{2}{*}{600} & & - & - & $99.44 \pm 0.60$ & $37.60 \pm 2.03$ & $100.01 \pm 0.45$ \\
\hline & & & & 0.60 & & 0.45 \\
\hline
\end{tabular}

*All values are mean \pm SD and $\%$ RSD for $n=3$
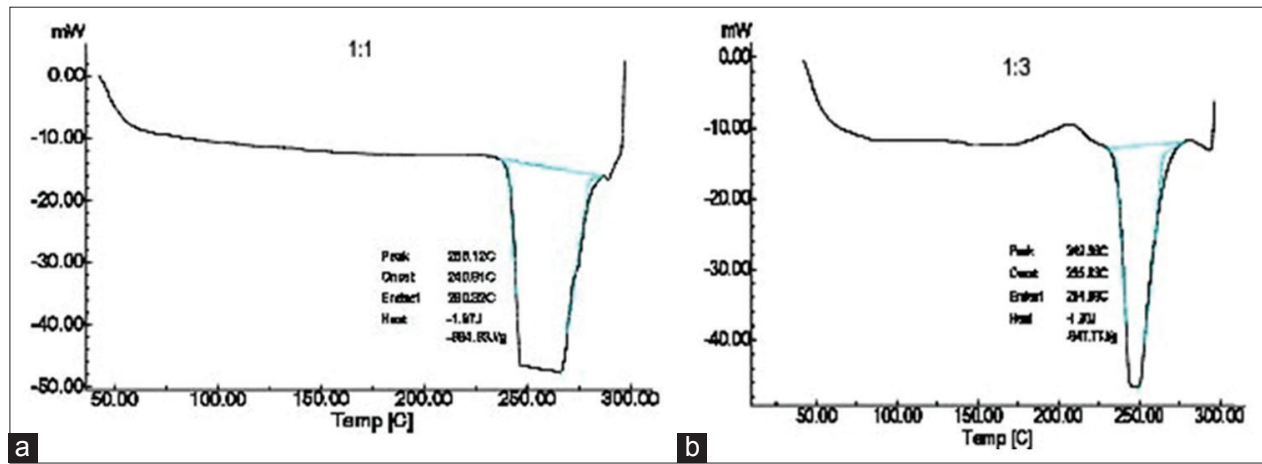

Fig. 1: Compatibility analysis of metformin hydrochloride and polymer(s) by differential scanning calorimetry. (a) Metformin hydrochloride. (b) Metformin hydrochloride and ethyl cellulose 
Table 5: Regression coefficient values (R2) of selected sustained release matrix tablets of metformin hydrochloride (formulations $\mathrm{F}_{3}$ and $\mathrm{FM}$ )

\begin{tabular}{llll}
\hline Formulations & 0 order $\mathbf{1}^{\text {st }}$ order & Higuchi model & Korsemeyer and Peppas model \\
\hline $\mathrm{F}_{3}$ & 0.8331 & 0.9784 & 0.9703 \\
$\mathrm{FM}$ & 0.8456 & 0.9948 & 0.9920 \\
& 0.8723 & & \\
\hline
\end{tabular}

Table 6: Stability studies of in vitro release profiles on tablet formulation $\mathrm{F}_{3}$ at room temperature $\left(25^{\circ} \mathrm{C} \pm 2^{\circ} \mathrm{C}\right.$ at $\left.60 \% \pm 5 \% \mathrm{RH}\right)$ in the period of 6-month*

\begin{tabular}{|c|c|c|c|c|c|c|c|}
\hline Time (minutes) & pH & $1^{\text {st }}$ Month & $2^{\text {nd }}$ Month & $3^{\text {rd }}$ Month & $4^{\text {th }}$ Month & $5^{\text {th }}$ Month & $6^{\text {th }}$ Month \\
\hline \multirow[t]{2}{*}{30} & pH 1.2 (simulated gastric fluid) & $15.79 \pm 1.12$ & $17.72 \pm 1.14$ & $16.47 \pm 1.94$ & $15.80 \pm 1.96$ & $17.27 \pm 2.06$ & $16.01 \pm 2.22$ \\
\hline & & 1.33 & 1.29 & 2.20 & 2.40 & 11.90 & 13.86 \\
\hline \multirow[t]{2}{*}{60} & & $23.09 \pm 1.50$ & $22.82 \pm 2.87$ & $23.00 \pm 1.20$ & $20.31 \pm 1.91$ & $23.40 \pm 2.65$ & $20.96 \pm 0.94$ \\
\hline & & 1.70 & 3.25 & 1.36 & 9.42 & 11.34 & 4.47 \\
\hline \multirow[t]{2}{*}{90} & & $30.84 \pm 1.23$ & $31.53 \pm 0.86$ & $28.72 \pm 1.78$ & $31.86 \pm 4.24$ & $31.21 \pm 3.91$ & $30.34 \pm 2.30$ \\
\hline & & 1.40 & 0.97 & 4.20 & 13.32 & 12.54 & 7.59 \\
\hline 120 & & $41.77 \pm 1.49$ & $41.93 \pm 2.69$ & $40.98 \pm 2.12$ & $40.01 \pm 0.84$ & $39.82 \pm 1.44$ & $39.54 \pm 2.09$ \\
\hline \multirow[t]{2}{*}{150} & pH 7.2 (simulated intestinal fluid) & $48.80 \pm 2.02$ & $49.39 \pm 1.80$ & $49.16 \pm 1.84$ & $48.46 \pm 2.23$ & $49.43 \pm 0.73$ & $48.78 \pm 1.93$ \\
\hline & & 2.29 & 2.04 & 2.08 & 4.61 & 1.48 & 3.95 \\
\hline \multirow[t]{2}{*}{180} & & $57.55 \pm 3.57$ & $57.65 \pm 1.78$ & $58.54 \pm 2.78$ & $57.87 \pm 3.00$ & $57.18 \pm 4.11$ & $57.86 \pm 5.13$ \\
\hline & & 4.40 & 2.01 & 3.15 & 5.19 & 7.18 & 8.87 \\
\hline \multirow[t]{2}{*}{240} & & $69.92 \pm 2.59$ & $70.65 \pm 1.78$ & $69.93 \pm 1.62$ & $70.14 \pm 2.8$ & $70.46 \pm 1.28$ & $68.62 \pm 1.92$ \\
\hline & & 2.94 & 2.87 & 1.83 & 2.97 & 1.82 & 2.79 \\
\hline \multirow[t]{2}{*}{360} & & $78.90 \pm 1.51$ & $81.06 \pm 3.22$ & $80.90 \pm 1.70$ & $78.36 \pm 2.47$ & $80.95 \pm 1.69$ & $80.43 \pm 3.39$ \\
\hline & & 1.71 & 3.64 & 1.92 & 3.15 & 2.08 & 4.21 \\
\hline 420 & & 3.04 & 2.29 & 2.64 & 1.99 & 2.45 & 1.81 \\
\hline \multirow[t]{2}{*}{600} & & $99.61 \pm 0.57$ & $99.79 \pm 0.31$ & $99.59 \pm 0.44$ & $97.25 \pm 0.24$ & $96.55 \pm 0.58$ & $95.13 \pm 1.11$ \\
\hline & & 0.65 & 0.35 & 0.49 & 0.25 & 0.68 & 1.16 \\
\hline
\end{tabular}

*All values are mean \pm SD and $\%$ RSD for $n=3$

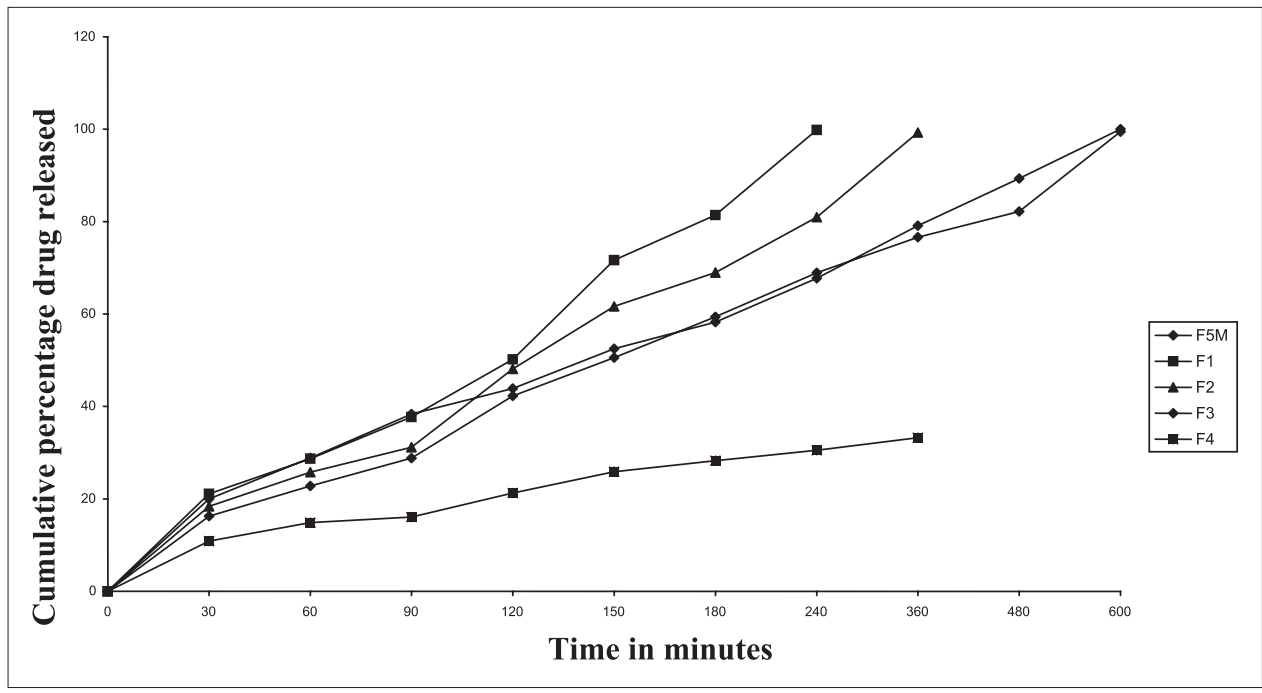

Fig 2: Plot of in vitro release profile in simulated gastric fluid (pH 1.2-acid buffer) (for first 2 hrs) followed by simulated intestinal fluid (pH 7.2-phosphate buffer) for ethyl cellulose based metformin hydrochloride matrix tablet formulations

Comprehensive data of in vitro release rate studies were showing $t_{25}$ (time of $25 \%$ drug release), $t_{50}$ (time of $50 \%$ drug release), and $t_{90}$ (time of $90 \%$ drug release) values were determined of formulation $\mathrm{F}_{3}$ at room and accelerated condition was shown in Fig. 3 (Tables 5 and 6). All the data of $t_{25}, t_{50}$, and $t_{90}$ in vitro release rate study values are applying paired $t$-test was shown in Table 10 . There is no significant difference between room and accelerated condition at $\mathrm{p}<0.001$ for formulation $\mathrm{F}_{3}$. Hence, the formulation $\mathrm{F}_{3}$ was selected best formulation.

\section{In vivo release studies}

From the $t$-test, comparison of $\mathrm{F}_{3}$ and reference standard $\left(\mathrm{F}_{5} \mathrm{M}\right)$ $t$ calculated value $<t$ table value $(0.001<2.34)$, therefore accepted the null hypothesis. There is no difference between $\mathrm{F}_{3}$ and $\mathrm{F}_{5} \mathrm{M}$. Hence, the formulation $\mathrm{F}_{3}$ was similar as the reference standard $\left(\mathrm{F}_{5} \mathrm{M}\right)$ to produced extended release to lower the blood glucose level in animal at tested dose level (Tables 11 and 12) [25-27]. The pharmacokinetic studies results were shown in Table 13 and Fig. 5. 


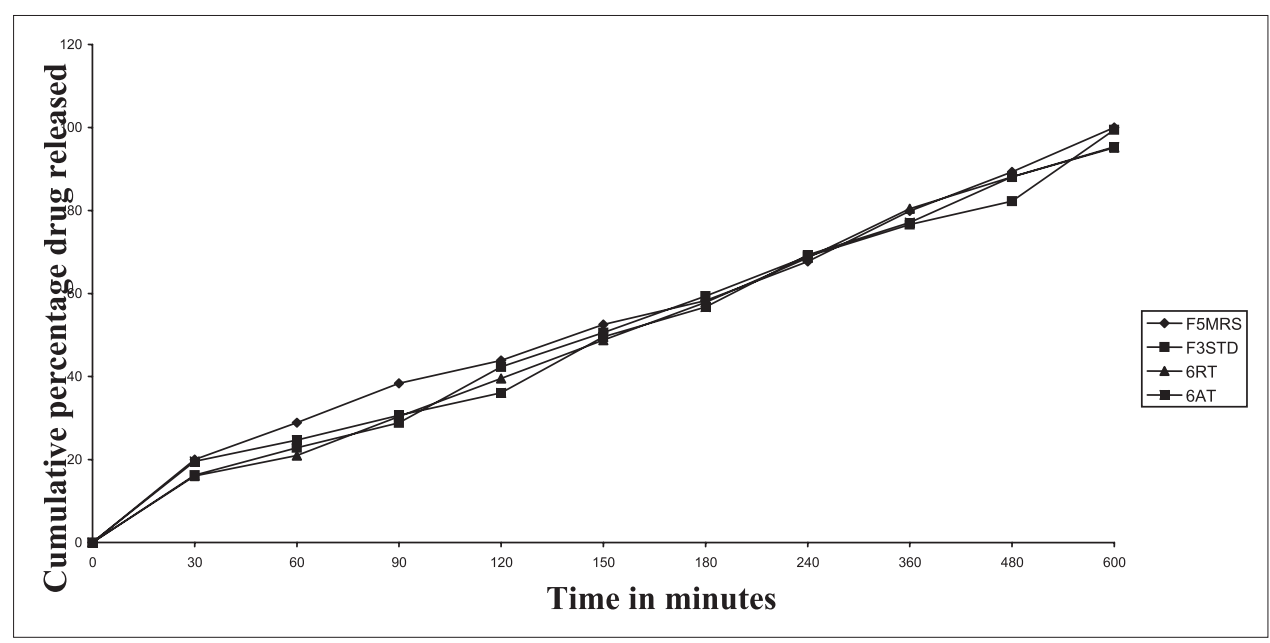

Fig. 3: Plot of stability studies on in vitro release profile at room temperature $\left(25^{\circ} \mathrm{C} \pm 2^{\circ} \mathrm{C}\right.$ and $\left.60 \% \pm 5 \% \mathrm{RH}\right)$ and accelerated temperature $\left(40^{\circ} \mathrm{C} \pm 2^{\circ} \mathrm{C}\right.$ and $\left.75 \pm 5 \% \mathrm{RH}\right)$ in simulated gastric fluid ( $\mathrm{pH} 1.2$-acid buffer) (for first $2 \mathrm{hrs}$ ) tablet formulations $\mathrm{F} 3$ for 6 months

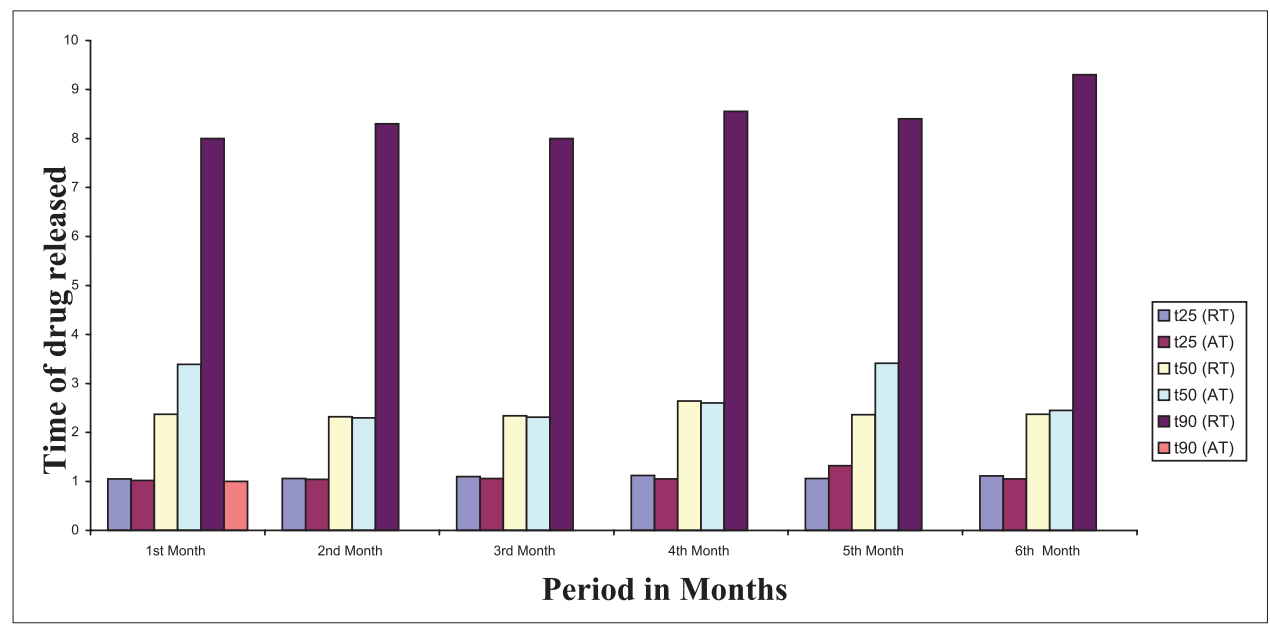

Fig. 4: Histogram of stability studies on in vitro release profile at room temperature $\left(25^{\circ} \mathrm{C} \pm 2^{\circ} \mathrm{C}\right.$ and $\left.60 \% \pm 5 \% \mathrm{RH}\right)$ and accelerated temperature $\left(40^{\circ} \mathrm{C} \pm 2^{\circ} \mathrm{C}\right.$ and $\left.75 \% \pm 5 \% \mathrm{RH}\right)$ of $\mathrm{t} 25 \mathrm{t} 50$ and t90 values for ethyl cellulose based metformin hydrochloride matrix tablet formulations F3 for 6 months

Table 7: Stability studies of in vitro release profiles on tablet formulation $\mathrm{F}_{3}$ at accelerated temperature $\left(40^{\circ} \mathrm{C} \pm 2^{\circ} \mathrm{C}\right.$ at $\left.75 \% \pm 5 \% \mathrm{RH}\right)$ in the period of 6-month*

\begin{tabular}{|c|c|c|c|c|c|c|c|}
\hline Time (minutes) & pH & $1^{\text {st }}$ Month & $2^{\text {nd }}$ Month & $3^{\text {rd }}$ Month & $4^{\text {th }}$ Month & $5^{\text {th }}$ Month & $6^{\text {th }}$ Month \\
\hline \multirow[t]{2}{*}{30} & pH 1.2 (Simulated gastric fluid) & $16.96 \pm 1.87$ & $17.39 \pm 1.08$ & $15.75 \pm 2.03$ & $14.48 \pm 1.97$ & $16.04 \pm 1.37$ & $19.52 \pm 0.53$ \\
\hline & & 2.12 & 1.22 & 2.30 & 13.63 & 8.52 & 2.71 \\
\hline \multirow[t]{2}{*}{60} & & $24.46 \pm 0.96$ & $23.46 \pm 1.36$ & $24.29 \pm 1.04$ & $23.00 \pm 1.57$ & $21.00 \pm 1.61$ & $24.68 \pm 0.82$ \\
\hline & & 1.08 & 1.54 & 1.20 & 6.56 & 7.65 & 3.30 \\
\hline \multirow[t]{2}{*}{90} & & $29.44 \pm 1.27$ & $29.19 \pm 2.45$ & $32.73 \pm 3.14$ & $30.31 \pm 1.44$ & $26.69 \pm 2.77$ & $30.62 \pm 2.72$ \\
\hline & & 1.44 & 2.77 & 3.56 & 4.75 & 9.33 & 8.90 \\
\hline \multirow[t]{2}{*}{120} & & $42.05 \pm 1.97$ & $41.04 \pm 2.12$ & $43.65 \pm 1.61$ & $39.62 \pm 3.46$ & $37.45 \pm 2.36$ & $36.05 \pm 0.63$ \\
\hline & & 2.23 & 2.40 & 1.82 & 8.74 & 6.30 & 1.74 \\
\hline \multirow[t]{2}{*}{150} & pH 7.2 (Simulated intestinal fluid) & $49.85 \pm 2.45$ & $49.62 \pm 1.04$ & $51.66 \pm 2.80$ & $46.93 \pm 2.77$ & $46.86 \pm 1.73$ & $49.53 \pm 2.73$ \\
\hline & & 2.77 & 1.78 & 3.17 & 5.90 & 3.69 & 5.51 \\
\hline \multirow[t]{2}{*}{180} & & $58.08 \pm 1.77$ & $59.00 \pm 1.44$ & $59.69 \pm 4.35$ & $56.42 \pm 2.25$ & $55.27 \pm 4.00$ & $56.75 \pm 1.63$ \\
\hline & & 2.00 & 2.29 & 4.92 & 4.00 & 7.37 & 2.87 \\
\hline \multirow[t]{2}{*}{240} & & $70.43 \pm 2.13$ & $68.95 \pm 2.37$ & $68.93 \pm 2.09$ & $65.87 \pm 3.20$ & $66.04 \pm 1.03$ & $69.26 \pm 2.47$ \\
\hline & & 2.41 & 2.69 & 2.37 & 4.85 & 1.56 & 3.57 \\
\hline \multirow[t]{2}{*}{360} & & $79.13 \pm 2.73$ & $79.21 \pm 2.17$ & $80.88 \pm 2.12$ & $76.70 \pm 3.06$ & $77.85 \pm 3.70$ & $77.10 \pm 2.31$ \\
\hline & & 3.09 & 2.45 & 2.40 & 3.98 & 4.75 & 3.00 \\
\hline \multirow[t]{2}{*}{420} & & $90.07 \pm 1.51$ & $87.63 \pm 2.15$ & $90.5 \pm 1.15$ & $86.08 \pm 1.64$ & $86.77 \pm 1.87$ & $88.11 \pm 2.61$ \\
\hline & & 1.71 & 2.44 & 1.30 & 1.90 & 2.16 & 2.96 \\
\hline \multirow[t]{2}{*}{600} & & $99.59 \pm 0.41$ & $99.54 \pm 0.49$ & $99.39 \pm 0.41$ & $96.88 \pm 0.29$ & $96.50 \pm 1.31$ & $95.35 \pm 1.14$ \\
\hline & & 0.47 & 0.55 & 0.46 & 0.30 & 1.36 & 1.20 \\
\hline
\end{tabular}

*All values are mean \pm SD and $\%$ RSD for $n=3$ 
Table 8: Stability studies on in vitro release profile of $t_{25}, t_{50}$, and $t_{90}$ on formulation $F_{3}$ at room temperature and accelerated temperature in the period of 6 months*

\begin{tabular}{|c|c|c|c|c|c|c|}
\hline \multirow{2}{*}{$\begin{array}{l}\text { Period in } \\
\text { month }\end{array}$} & \multicolumn{3}{|c|}{ Room temperature $\left(25^{\circ} \mathrm{C} \pm 2^{\circ} \mathrm{C}\right.$ at $\left.60 \% \pm 5 \% \mathrm{RH}\right)$} & \multicolumn{3}{|c|}{ Accelerated temperature $\left(40^{\circ} \mathrm{C} \pm 2^{\circ} \mathrm{C}\right.$ at $75 \% \pm 5 \% \mathrm{RH}$} \\
\hline & $t_{25}$ (hrs) & $t_{50}$ (hrs) & $t_{90}$ (hrs) & $t_{25}$ (hrs) & $t_{50}$ (hrs) & $t_{90}$ (hrs) \\
\hline $1^{\text {st }}$ month & 1.05 & 2.37 & 8.10 & 1.02 & 3.39 & 8.00 \\
\hline $3^{\text {rd }}$ month & 1.10 & 2.34 & 8.20 & 1.06 & 2.31 & 8.00 \\
\hline $4^{\text {th }}$ month & 1.12 & 2.64 & 8.32 & 1.05 & 2.60 & 8.55 \\
\hline $5^{\text {th }}$ month & 1.06 & 2.36 & 8.00 & 1.32 & 3.41 & 8.40 \\
\hline $6^{\text {th }}$ month & 1.11 & 2.37 & 8.30 & 1.05 & 2.45 & 9.30 \\
\hline
\end{tabular}

*All values are mean for $n=3$

Table 9: Regression coefficient values (R2) of selected sustained release matrix tablets of Metformin hydrochloride (formulations $F_{3}$ and FM) after 12 month of stability studies at $25^{\circ} \mathrm{C} \pm 2{ }^{\circ} \mathrm{C}$ at $60 \% \pm 5 \% \mathrm{RH}$

\begin{tabular}{lllll}
\hline Formulations & 0 order & $\mathbf{1}^{\text {st }}$ order & Higuchi model & Korsmeyer and Peppas model \\
\hline$F_{3}$ & 0.9831 & 0.9911 & 0.9781 & 0.9669 \\
FM & 0.9675 & 0.9528 & 0.9950 & 0.9912 \\
\hline
\end{tabular}

RH: Relative humidity

Table 10: Regression coefficient values (R2) of selected sustained release matrix tablets of metformin hydrochloride (formulations $F_{3}$ and FM) after 6 months of stability studies at $40^{\circ} \mathrm{C} \pm 2^{\circ} \mathrm{C}$ at $75 \% \pm 5 \% \mathrm{RH}$

\begin{tabular}{lllll}
\hline Formulations & 0 order & $\mathbf{1}^{\text {st }}$ order & Higuchi model & Korsmeyer and Peppas model \\
\hline $\mathrm{F}_{3}$ & 0.8976 & 0.9833 & 0.9815 & 0.9676 \\
$\mathrm{FM}$ & 0.9576 & 0.9921 & 0.9896 & 0.9860 \\
\hline
\end{tabular}

RH: Relative humidity

Table 11: t-test descriptive statistics for determination of blood glucose level by animal studies for formulation $F_{3}$ and reference standard $\left(\mathrm{F}_{5} \mathbf{M}\right)^{*}$

\begin{tabular}{|c|c|c|c|c|c|c|c|c|}
\hline \multirow[t]{2}{*}{ Group } & \multirow{2}{*}{$\begin{array}{l}\text { Treatment } \\
\text { (dose, mg/kg) }\end{array}$} & \multicolumn{7}{|c|}{ Blood sugar in mg/dl (hrs) \pm SEM } \\
\hline & & $\mathbf{0}$ & 1 & 2 & 4 & 6 & 8 & 10 \\
\hline I & Normal (control) & $99.67 \pm 2.26$ & $100.12 \pm 2.02$ & $97.13 \pm 1.89$ & $102.44 \pm 2.10$ & $110.39 \pm 2.31$ & $95.91 \pm 1.76$ & $103.33 \pm 1.74$ \\
\hline III & $\begin{array}{l}\text { Formulation } \\
\mathrm{F}_{3}(450)\end{array}$ & $483.83 \pm 3.91$ & $474.33 \pm 4.10$ & $458.00 \pm 4.62$ & $433.83 \pm 5.25$ & $397.67 \pm 4.78$ & $321.50 \pm 3.31$ & $309.00 \pm 3.66$ \\
\hline IV & $\begin{array}{l}\text { Reference standard } \\
\mathrm{F}_{5} \mathrm{M}(450)\end{array}$ & $499.83 \pm 1.66$ & $492.17 \pm 2.01$ & $469.17 \pm 2.55$ & $436.50 \pm 3.91$ & $390.33 \pm 3.91$ & $333.00 \pm 3.76$ & $339.67 \pm 3.95$ \\
\hline
\end{tabular}

*All values are mean \pm standard mean error for $n=6$

Table 12: t-test inferential studies for determination of blood glucose level by animal studies for formulation $F_{3}$ with reference standard ( $F_{5} M$ )

\begin{tabular}{|c|c|c|c|c|c|c|}
\hline Formulations & Mean & Standard deviation & Degree of freedom & t calculated value & t table value & p value \\
\hline $\mathrm{F}_{3}$ & 423.09 & 53.30 & 10 & 0.003 & 2.34 & $\mathrm{p}>0.01$ \\
\hline $\mathrm{F}_{5}^{3} \mathrm{M}$ & 422.80 & 69.75 & - & - & - & \\
\hline
\end{tabular}

Table 13: Mean plasma drug concentration of metformin hydrochloride matrix tablet formulation of reference standard, FM, $\mathbf{F}_{3}$

\begin{tabular}{llll}
\hline Time (hrs) & \multicolumn{2}{l}{$\begin{array}{l}\text { Mean plasma drug } \\
\text { concentration } \pm \text { standard deviation } \\
(\mathbf{n g} / \mathbf{m l})\end{array}$} & \\
\cline { 2 - 4 } & $\mathbf{R S}$ & $\mathbf{F M}$ & $\mathbf{F}_{3}$ \\
\hline 0 & 0 & 0 & 0 \\
0.5 & $1.26 \pm 0.09$ & $1.24 \pm 0.14$ & $1.10 \pm 0.10$ \\
1 & $1.47 \pm 0.08$ & $1.31 \pm 0.13$ & $1.22 \pm 0.09$ \\
2 & $2.15 \pm 0.15$ & $1.69 \pm 0.04$ & $1.60 \pm 0.02$ \\
4 & $0.91 \pm 0.11$ & $0.95 \pm 0.06$ & $0.91 \pm 0.11$ \\
6 & $0.05 \pm 0.01$ & $0.70 \pm 0.06$ & $0.60 \pm 0.09$ \\
8 & $0.05 \pm 0.02$ & $0.34 \pm 0.07$ & $0.32 \pm 0.09$ \\
\hline
\end{tabular}

\section{CONCLUSION}

Based on in vitro $\mathrm{t}_{25}, \mathrm{t}_{50}$ and $\mathrm{t}_{90}$ and in vivo drug release, formulation $\mathrm{F}_{3}$ was found to have a selective drug release pattern among the formulations prepared. The values were compared with a reference standard $\left(\mathrm{F}_{5} \mathrm{M}\right)$ and were subjected to stability study at room and accelerated temperature to find out the effect of aging on release pattern. The result of this stability study does not indicate any significant alteration in the in vitro release pattern of the drug from the matrix tablet. Formulation $\mathrm{F}_{3}$ found to be stable on storage and does not exhibit any alteration in its release pattern. Hence, it was concluded that formulation, $F_{3}$ was selected as best formulation.

\section{ACKNOWLEDGMENTS}

The author is grateful to the Managing Director and Correspondent, Adhiparasakthi College of Pharmacy, Melmaruvathur, Tamil Nadu, India 


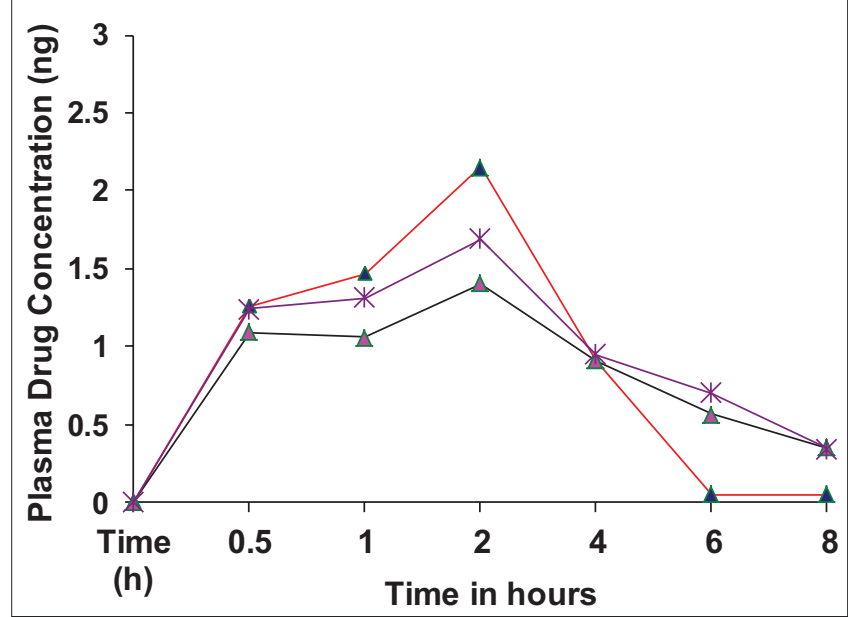

Fig. 5: Plasma drug concentration versus time curve of metformin hydrochloride matrix tablet formulations of F3, FM reference standard in rabbit

for providing necessary facilities and encouragement to carry out this work.

\section{REFERENCES}

1. Stith BJ, Goalstone ML, Espinoza R, Mossel C, Roberts D, Wiernsperger N. The antidiabetic drug metformin elevates receptor tyrosine kinase activity and inositol 1, 4, 5-trisphosphate mass in Xenopus oocytes. Endocrinology 1996;137(7):2990-9.

2. Dunn CJ, Peters DH. Metformin. A review of its pharmacological properties and therapeutic use in non-insulin-dependent diabetes mellitus. Drugs 1995;49(5):721-49.

3. Balan $\mathrm{G}$, Timmins $\mathrm{P}$, Greene DS, Marathe PH. In vitro-in vivo correlation (IVIVC) models for metformin after administration of modified-release (MR) oral dosage forms to healthy human volunteers. J Pharm Sci 2001;90(8):1176-85.

4. Defang O, Shufang N, Wei L, Hong G, Hui L, Weisan P. In vitro and in vivo evaluation of two extended release preparations of combination metformin and glipizide. Drug Dev Ind Pharm 2005;31(7):677-85.

5. Montvale NJ. Physician's Desk Reference. $53^{\text {th }}$ ed. Montvale, NJ Thompson PDR; 1999.

6. Rao KR, Senapati P, Das MK. Formulation and in vitro evaluation of ethyl cellulose microspheres containing zidovudine. J Microencapsul 2005;22(8):863-76

7. Srivastava AK, Ridhurkar DN, Wadhwa S. Floating microspheres of cimetidine: Formulation, characterization and in vitro evaluation. Acta Pharm 2005;55(3):277-85

8. Wu PC, Huang YB, Chang JI, Tsai MJ, Tsai YH. Preparation and evaluation of sustained release microspheres of potassium chloride prepared with ethylcellulose. Int J Pharm 2003;260(1):115-21.

9. Dinarvand R, Mirfattahi S, Atyabi F. Preparation, characterization and in vitro drug release of isosorbide dinitrate microspheres. J Microencapsul 2002;19(1):73-81.

10. Ray S, Ghosh PK, Das B, Shosh LK Gupta BK. Statistical optimization supported product development of anti-asthamatic multiparticulate drug delivery system. Indian J Pharm Sci 2000;62(3):175-80.

11. Botha SA, Lotter AP. Compatibility study between atenolol and tablet excipients using differential scanning calorimetry. Drug Dev Indian Pharm 1990;16:1945-54.

12. Vueba ML, Veiga F, Sousa JJ, Pina ME. Compatibility studies between ibuprofen or ketoprofen with cellulose ether polymer mixtures using thermal analysis. Drug Dev Ind Pharm 2005;31(10):943-9.

13. Levy G, Reuning RH. Effect of complex formation on drug absorption. I: Complexes of salicylic acid with absorbable and nonabsorbable compounds. J Pharm Sci 1964:53:1472.

14. Wan Pao Li A, Mrose PV. ???. Int J Pharm 1984;18:287.

15. Banker GS, Anderson LR. Theory and Practice of Industrial Pharmacy, $3^{\text {rd }}$ ed. Mumbai, India: Varghese Publishing House, 1987. p. 296-329.

16. Aulton ME, Wells T. Pharmaceutics. The Science of Dosage form Design, $4^{\text {th }}$ ed. London: Churchill Livingstone; 1998. p. 667-71.

17. Patrick Martin's JS. Physical Pharmacy and Pharmaceutical Sciences. $5^{\text {th }}$ ed. Indian, London: Lippincott Williams and Wilkins; 2006. p. $533-60$.

18. Lachman L, Libermann HA. The theory practice of industrial pharmacy, $4^{\text {th }}$ ed. Mumbai: Varghese Publishing House; 1987. p. 293.

19. United States Pharmacopoeia. Vol. 2. United States Pharmacopoeial Conversion, Inc; 1995. p. 323.

20. India Pharmacopoeia. The controller of Publications of India. Vol. II. New Delhi: India Pharmacopoeia; 1996. p. A82-4.

21. Anonymous. British Pharmacopoeia. Vol. II. London: Spottiswoode \& co.; 1993. p. A79.

22. Wal Pole RW, Myer RH. Probability and Statistics for Engineers and Scientists. $4^{\text {th }}$ ed. Canada: Collier Macmillan; 1986. p. 473-92.

23. Sundar Rao PS, Richar Chand J. Introduction to Biostatistics and Research Methods, $4^{\text {th }}$ ed. New Delhi: Prentice Hall of India Private Limited; 2006. p. 102-7.

24. Manavalan R, Ramasamy S. Physical Pharmaceutics, Accelerated stability Testing. $2^{\text {nd }}$ ed. Chennai: Vignesh Publisher; 2004. p. 288-99.

25. Srinivas SS, Rao ME, Rao B. Investigation on the anti-diabetic activity of Raphanus sativus Linn. Indian Drugs 2000;37(9):445-7.

26. Sambasivarao SV, Hanumantharao P, Kaskheclikar GG. ???. Indian Drugs 2005;42(50):261-7.

27. Bopanna KN, Kannan J, Gadgil RS, Balaraman R, Rathod SP Antidiabetic and anti hyperlipemic effects of neem seed kernal powder on alloxan diabetic rabbits. Indian J Pharmacol 1997;29:162-7. 